\title{
Broiler Sürülerinde Ornithobacterium rhinotracheale İnfeksiyonunun Seroprevalansının ELISA Yöntemi ile Araştırılması
}

\author{
Cenk Güllüi1, Göksel Erbaş² \\ ${ }^{1}$ Adnan Menderes Üniversitesi Sağllk Bilimleri Enstitüsü, Mikrobiyoloji Anabilim Dalı \\ ${ }^{2}$ Adnan Menderes Üniversitesi Veteriner Fakültesi, Mikrobiyoloji Anabilim Dalı
}

Geliş Tarihi / Received: 08.12.2018, Kabul Tarihi / Accepted: 06.05.2018

\begin{abstract}
Özet: Gram negatif bir bakteri olan Ornithobacterium rhinotracheale (ORT), solunum yolu hastalığına sebebiyet veren en önemli patojen etkenler arasında yer almaktadır. ORT hastalığı, tüm dünyada kanatlı endüstrisinde ağır ekonomik kayıplara neden olan, daha çok tavuk ve hindilerde görülen, akut seyirli, yüksek düzeyde bulaşıcı olan bir üst solunum yolu hastalığıdır. Bu çalışmada, Aydın, İzmir ve Manisa illerindeki ticari broiler yetiştirilen kümeslerde, üst solunum yollarında hastalığa ve yüksek verim kayıplarına neden olabilen, Ornithobacterium rhinotracheale bakterisinin neden olduğu ORT hastalığının serolojik prevalansının saptanması amaçlanmıştır. Örneklemede Aydın, İzmir ve Manisa illerindeki ticari Broiler yetiștiriciliği yapılan farklı kümeslerden toplanan 420 adet kan örneği kullanılmıștır. Her üç ilden de 140'ar örnek toplanmıştır. Her ildeki 5'er farklı çiftlikten kesim zamanında 28'er adet serum örneği alındı. Toplam 420 adet kan serumunun ELISA testi ile ORT yönünden değerlendirmesinde pozitiflik oran1 \%55.2 (232 pozitif - 188 negatif) olarak bulunmuştur. Aydın ilindeki pozitiflik oran $\% 40.8$, İzmir ilindeki pozitiflik oranı \%68.6, Manisa ilindeki pozitiflik oranı ise \%56.4 olarak tespit edilmiştir. Çalışma sonuçları genel olarak değerlendirildiğinde her üç ildeki sero-pozitiflik oranları da oldukça yüksek bulunmuştur. Pozitiflik oranlarındaki bu yükseklik göz önüne alındığında hastalıkla ilgili daha ayrıntılı çalışmaların planlanmasının gerekliliği ortaya çıkmaktadır. İleriki çalışmalarda serolojik araştırmaların tüm ülke bazında planlanarak yapılması ve de etkenin tam identifikasyonunun yapılarak antibiyotik dirençlilik profilinin çıkarılması hastalıkla mücadele açısından yararlı olacaktır.
\end{abstract}

Anahtar kelimeler: Broiler, ELISA, Ornithobacterium rhinotracheale

\section{Investigation of the seroprevalence of Ornithobacterium rhinotracheale infection in broiler hens by ELISA}

\begin{abstract}
Ornithobacterium rhinotracheale (ORT), a Gram-negative bacterium, is one of the most important pathogenic agents causing respiratory disease. ORT disease is an acute, highly contagious upper respiratory tract disease seen mostly in chickens and in turkeys, causing severe economic losses in poultry industry all over the world. In this study, it was aimed to determine the serological prevalence of ORT disease in broiler poultry in Aydın, İzmir and Manisa provinces causing upper respiratory tract diseases and high yield losses. For the sampling; 420 blood samples were used and collected from different clusters of Aydın, Izmir and Manisa. A total of 140 samples were collected from each city. Twenty-eight different serum samples were taken at the time of slaughtering from 5 different farms on each side. When a total of 420 blood serum samples were evaluated by ELISA for ORT, the positivity rate was 55.2\% (232 positive - 188 negative). The positivity rate in Aydın was $40.8 \%$, İzmir was $68.6 \%$ and the Manisa was $56.4 \%$. When the results of the study were evaluated in general, the sero-positivity rates of all three cities were found to be quite high. Considering this high level of positivity, it is necessary to plan more detailed studies about the disease in the near future. In future studies, planning serologic surveys all over the country, as well as the identification of the antibiotic resistance profile by making full identification of the agent will be helpful in combating the disease.
\end{abstract}

Key words: Broiler, ELISA, Ornithobacterium rhinotracheale

\section{Giriș}

Kanatlı endüstrisinin gelişiminde hastalıklar büyük problem teşkil etmektedir. Bunlar içerisinde solunum sistemi hastalıkları önemli rol oynamaktadır [3]. Kanatlilarda solunum yolu hastalıkları bakteriler, mantarlar ve virüsler gibi çeşitli patojenlerden kaynaklanır [7]. Ornithobacterium rhinotracheale
(ORT), solunum yolu hastalığına bağlı ortaya ç1kan bir kanatlı patojenidir [11]. ORT, yakın zamanda dünyanın birçok ülkesinden izole edilmiştir. Ornithobacterium rhinotracheale, diğer mikroorganizmalarla da sinerji oluşturarak, mortalitenin yükselmesine, ilaç maliyetlerinin artması, yumurta üretimindeki düşüşlere ve yumurta kabuğu kalitesinin 
azalması gibi etkilerinden dolayı ciddi ekonomik kayılara neden olabilmektedir [17]. ORT, Gramnegatif, pleomorfik, çubuk şeklinde, hareketsiz bir bakteridir ve kanatlilarda en önemli patojenlerden biri olarak düşünülmektedir $[16,18]$.

Şu ana kadar yapılan çalışmalarda ORT'nin en az 18 ORT serotipi olduğu bildirilmektedir. Tavuklarda yapılan serotiplendirme çalışmaları sonucunda, elde edilen izolatların çoğunluğunun A serotipi olduğu ve suşların $\% 95$ 'inin ise $\mathrm{A}, \mathrm{B}, \mathrm{D}$ ve $\mathrm{E}$ serotiplerine ait olduğunu ortaya konmuştur [7]. O. rhinotracheale'nin serolojik tanısı için ELISA ve agar jel presipitasyon (AGP) testi kullanılmaktadır. AGP özellikle serotiplendirme için tercih edilen bir yöntemdir. ELISA, ORT'ye karş1 antikor varlığını bulmak için günümüzde en doğru ve güvenilir yöntemdir [5]. ELISA serotip spesifitesi ELISA plakalarını kaplamak için kullanılan antijen ekstraksiyon metoduna bağlıdır. O. rhinotracheale'ye karşı antikorların varlığının görülebilmesi için, her yaşta, ya da klinik bulguların görüldüğü kanatlılarda tanısal amaçlar için ELISA testi kullanılabilmektedir [13].

ORT enfeksiyonunun görülme sıklığı ile ilgili ülkemizde geçmiş yıllarda da bazı araştırmalar yapılmıştır $[2,12,13,14]$. Bu araştırmalar incelendiğinde antikor pozitifliğinin (\%50-60 aralığında) oldukça yüksek denebilecek düzeylerde olduğu görülmektedir. Bu yüksek yüzdeler göz önüne alınd1ğında sollunum yolu hastalıkları içerisinde düzenli olarak mücadelesi yapılmayan ORT hastalığı ile ilgili gerekli önlemlerin alınması için çalışmalar yapılması gerekliliği ve bu tip serolojik çalışmaların önemi bir kez daha ortaya çıkmaktadır.

$\mathrm{Bu}$ çalışmada, Türkiye'nin batı bölgelerinde yoğun kümes hayvanı yetiştiriciliği yapılan Aydın, İzmir ve Manisa illerindeki Ticari Broiler yetiştirilen kümeslerde, Üst solunum yollarında hastalığa, yüksek verim kayıplarına ve de bundan dolayı önemli maddi zararlara neden olabilen, Ornithobacterium rhinotracheale bakterisinin neden olduğu ORT hastalığının ELISA yöntemi ile serolojik prevalansının saptanması amaçland1.

\section{Materyal ve Metot}

\section{Örnekler}

Çalışmada Aydın, İzmir ve Manisa illerindeki ticari Broiler yetiştiriciliği yapılan farklı kümeslerden toplanan 420 adet kan örneği kullanıldı. Her üç ilden 140'ar örnek toplandi. Bahsi geçen bu 140 örnek her ildeki 5'er farklı çiftlikten 28 'er adet serum örneğinden meydana gelmektedir. Örnekler genel olarak kesim aşamasına gelmiş olan ve etçi amaçlı yetiştirilen 35-45 günlük yaştaki broiler sürülerinden 2017 yılının Mayıs ayı içerisinde alındı. Broilerlerden kan örneklerinin alınması kesim aşamasında gerçekleştirildi. Kanatlılar kesimhaneye getirildiklerinde rasgele seçilmişler ve usulüne uygun bir şekilde kanat alt yüzeyindeki venin dezenfeksiyonu sağlanmış ve iğne ile damara girilerek her bir hayvandan 4-5 ml kadar kan alındı. Kan alımını takiben ven tekrar dezenfeksiyonla temizlenip, hafif bası uygulanarak kanamanın durması sağland1. Elde edilen kanların serumları çıkartılarak ependorf tüplere aktarıldı. Serumlar çalış1lıncaya kadar $-20^{\circ} \mathrm{C}^{\prime}$ lik derin dondurucuda saklandi.

\section{Serolojik test}

Serum örneklerinde Ornithobacterium rhinotracheale antikor tespiti Enzyme-Linked Immunosorbent Assay (ELISA) testi ile belirlenmiştir. ELISA testi için (BioCheck, Millfield Road, Hounslow, Londra) ticari olarak hazırlanmış ELISA kiti üretici firmanın talimatları doğrultusunda kullanılmıştır. Testte k1saca numuneler 1/100 oranında seyreltildi ve OD (Optical Density) değerleri bir ELISA platyt okuyucusu (Biotek ELX800M, USA) üzerinde 405 nm'de ölçüldü. Sonuçlar, numunenin pozitif $(\mathrm{S} / \mathrm{P})$ oranı hesaplanarak belirlendi. S/P oran1 0.999 veya daha düşük olan örnekler negatif kabul edildi ve 1'den yüksek S/P değerleri olan örnekler pozitif kabul edildi. S/P oranlarının hesaplanması ve pozitiflik ve negatiflik sonuçlarının oluşturulmasında BioCheck (Millfield Road, Hounslow, Londra) firmasinın temin ettiği bilgisayar programından yararlanılmıştır. Çalışma sonucu elde edilen verilerin istatistiksel değerlendirmesinde SPSS 22.0 (PASW Inc., Chicago. IL. USA) Paket programı kullanılmıştır ve Ki kare $\left(\mathrm{X}^{2}\right)$ testi uyguland1.

\section{Bulgular}

Araştırma sonuçlarında her üç ilin toplamında çaliş1lan 420 adet kan serumunun ELISA testi ile ORT yönünden değerlendirmesinde pozitiflik oranı $\% 55.2$ (232 pozitif - 188 negatif) olarak tespit edildi (Tablo 1). 
Tablo 1. İllere göre ve toplam ORT ELISA test sonuçları

\begin{tabular}{lccccc}
\hline ILLER & \multicolumn{7}{c}{ Negatif } & Pozitif & Negatif \% & Pozitif \% & Numune \\
\hline AYDIN & 83 & 57 & 59.2 & 40.8 & 140 \\
IZMIR & 44 & 96 & 31.4 & 68.6 & 140 \\
MANISA & 61 & 79 & 43.6 & 56.4 & 140 \\
Toplam & $\mathbf{1 8 8}$ & $\mathbf{2 3 2}$ & $\mathbf{4 4 . 8}$ & $\mathbf{5 5 . 2}$ & $\mathbf{4 2 0}$ \\
\hline
\end{tabular}

Test sonuçları her il için kümes bazında ayrı ayrı değerlendirildiğinde;

Aydın ilindeki toplam 140 örnekte pozitiflik oran $\% 40.8$ (57 pozitif - 83 negatif) olarak tespit edilmiştir (Tablo 2).

Tablo 2. Aydın ili Broiler çiftlikleri ORT ELISA test sonuçları

\begin{tabular}{lcccccc}
\hline AYDIN İLİ & Gün & Negatif & Pozitif & Negatif \% & Pozitif \% & Numune \\
\hline KÜMES A & 44 & 13 & 15 & 46.4 & 54.6 & 28 \\
\hline KÜMES B & 42 & 8 & 20 & 28.5 & 71.5 & 28 \\
\hline KÜMES C & 43 & 19 & 9 & 67.8 & 32.2 & 28 \\
KÜMES D & 38 & 25 & 3 & 89.3 & 10.7 & 28 \\
\hline KÜMES E & 43 & 18 & 10 & 64.3 & 35.7 & 28 \\
Toplam & $\mathbf{4 2}$ & $\mathbf{8 3}$ & $\mathbf{5 7}$ & $\mathbf{5 9 . 2}$ & $\mathbf{4 0 . 8}$ & $\mathbf{1 4 0}$ \\
\hline
\end{tabular}

İzmir ilindeki toplam 140 örnekte pozitiflik oran1 $\% 68,6$ (96 pozitif - 44 negatif) olarak tespit edilmiştir (Tablo 3).

Tablo 3. İzmir ili Broiler çiftlikleri ORT ELISA test sonuçları

\begin{tabular}{lccccccc}
\hline İMÍR İLI & Gün & Negatif & Pozitif & Negatif \% & Pozitif \% & Numune \\
\hline KÜMES A & $\mathbf{4 2}$ & 17 & 11 & 60.7 & 39.3 & 28 \\
KÜMES B & 44 & 5 & 23 & 17.9 & 82.1 & 28 \\
\hline KÜMES C & 41 & 16 & 12 & 57.1 & 42.9 & 28 \\
KÜMES D & 43 & 4 & 24 & 14.3 & 85.7 & 28 \\
KÜMES E & 42 & 2 & 26 & 7.1 & 92.9 & 28 \\
Toplam & $\mathbf{4 2 . 4}$ & $\mathbf{4 4}$ & $\mathbf{9 6}$ & $\mathbf{3 1 . 4}$ & $\mathbf{6 8 . 6}$ & $\mathbf{1 4 0}$ \\
\hline
\end{tabular}

Manisa ilindeki toplam 140 örnekte pozitiflik oran1 \%56.4 (79 pozitif - 61 negatif) olarak tespit edilmiştir (Tablo 4).

Tablo 4. Manisa ili Broiler çiftlikleri ORT ELISA test sonuçları

\begin{tabular}{lcccccc}
\hline MANiSA İLI & Gün & Negatif & Pozitif & Negatif \% & Pozitif \% & Numune \\
\hline KÜMES A & 40 & 13 & 15 & 46.4 & 53.6 & 28 \\
KÜMES B & 39 & 10 & 18 & 35.7 & 64.3 & 28 \\
\hline KÜMES C & 43 & 2 & 26 & 7.1 & 92.9 & 28 \\
KÜMES D & 43 & 15 & 13 & 53.6 & 46.4 & 28 \\
KÜMES E & 41 & 21 & 7 & 75.0 & 25.0 & 28 \\
Toplam & $\mathbf{4 1 . 2}$ & $\mathbf{6 1}$ & $\mathbf{7 9}$ & $\mathbf{4 3 . 6}$ & $\mathbf{5 6 . 4}$ & $\mathbf{1 4 0}$ \\
\hline
\end{tabular}

İller bazında ORT antikoru görülme olasılığg bakımından beklenilen düzeyde pozitif veya negatif serum örneği gözlenip gözlenmediğini test etmek için Ki-kare $\left(\mathrm{X}^{2}\right)$ testinden yararlanılmıştır. Sonuçları içeren tüm veriler Tablo 5'de verilmektedir. Bu sonuçlara göre İzmir ilindeki ORT pozitiflik oranı beklenilen frekanstan önemli derecede yüksek, Aydın ilinde düşük, Manisa ilinde ise beklenen düzeye yakın bulunmuştur $(\mathrm{p}<0,001)$.

Tablo 5. Çalışma sonuçlarının genel değerlendirilmesi

\section{ÍLLER ARASI SONUÇLAR}

\begin{tabular}{clccc}
\hline & & \multicolumn{2}{c}{ Antikor } & \\
\cline { 3 - 4 } & & Negatif & Pozitif & \\
\hline \multirow{4}{*}{ AYDIN } & Adet & 83 & 57 & 140 \\
& $\%$ İl içi & $\% 59.3$ & $\% 40.7$ & $\% 100.0$ \\
& $\%$ Antikor & $\% 44.1$ & $\% 24.6$ & $\% 33.3$ \\
\multirow{4}{*}{ İZMIR } & Adet & 44 & 96 & 140 \\
& $\%$ İl içi & $\% 31.4$ & $\% 68.6$ & $\% 100.0$ \\
& $\%$ Antikor & $\% 23.4$ & $\% 41.4$ & $\% 33.3$ \\
\multirow{4}{*}{ MANISA } & Adet & 61 & 79 & 140 \\
& $\%$ İ içi & $\% 43.6$ & $\% 56.4$ & $\% 100.0$ \\
& $\%$ Antikor & $\% 32.4$ & $\% 34.1$ & $\% 33.3$ \\
\hline \multirow{2}{*}{ Toplam } & Adet & $\mathbf{1 8 8}$ & $\mathbf{2 3 2}$ & $\mathbf{4 2 0}$ \\
\cline { 2 - 4 } & Toplam \% & $\mathbf{\% 4 4 . 8}$ & $\mathbf{9 5 5 . 2}$ & $\mathbf{\% 1 0 0 . 0}$ \\
\hline
\end{tabular}

$\mathrm{X}^{2}=22.090 * * *, \quad * * *=\mathrm{P}<0.001$

\section{Tartışma ve Sonuç}

$\mathrm{Bu}$ araştırmada Aydın, İzmir ve Manisa illerinden alınan toplam 420 adet kan serumunun \%55.2'si (232 pozitif, 188 negatif) Ornithobacterium rhinotracheale antikorları açısından pozitif bulundu. Turan ve Ak [13] Marmara ve Karadeniz bölgelerindeki farklı çiftliklerde yaptıkları serolojik çalışmalarda $\% 65$ oranında serum pozitifliği saptamışlardır. O. rhinotracheale infeksiyonunun seroprevalansın ticari bir ELISA kiti ile belirlendiği ve Güney Marmara bölgesinde yürütülen başka bir çalıșmada ise incelenen 821 serum örneğinin 440'1 (\%53.59) $O$. rhinotracheale antikorları yönünden pozitif saptanmıştır [4]. Özbey ve ark. [12] Elazı̆̆'da yapmış oldukları çalışmada tavuklardan toplanan 324 serum örneğinde ELISA testi kullanarak ORT antikorları açısından \%10.2 (33 adet) pozitiflik saptandığını bildirmişlerdir. Araştırmalarında 10 adet broiler çiftliğinden ikisinde pozitiflik bulunmuştur. 
Sonuçlar açısından araştırmamızla karşılaştırıldığında büyük bir farklılık gözükmektedir. Özbey ve ark. [12] çalışmalarında kullandıkları tavukların oldukça genç olmasının bu farklılı̆̆ yaratabileceğini bildirmektedirler. Çünkü antikor titreleri genellikle enfeksiyon sonrası 1 ila 4 hafta arasında en yüksek seviyeye ulaşmakta ve tespit edilebilmektedir [16]. Türkyılmaz ve Kaya [14] Aydın ilinde 267 tavuk örneği ile yaptığ 1 çalışmasında ELISA testi ile \%66.3 oranında seropozitiflik saptamıştır ve çalışmaları Aydın ilinde ORT hastalığının ELISA ile değerlendirildiği ilk çalışmadır. Çalışmamızda yalnızca Aydın ili sonuçlarımız değerlendirildiğinde $\% 40.8$ lik bir pozitiflik saptanmıştır. Bu da Türkyılmaz ve Kaya [14] ile Turan ve Ak [13]'ın sonuçlarından biraz düşük olmasına rağmen her üç ilin toplam sonuçlarına incelendiğinde (\% 55.2) benzer sonuçlara ulaşılmaktadır. Çalışma sonuçları Aşyemez' in [4] sonuçları ile ise oldukça paralellik göstermektedir.

Aras ve ark. [2], ticari yumurtacı tavuk işletmelerinde bulunan tavuklarda Ornithobacterium rhinotracheale enfeksiyonunun serolojik prevalansının belirlenmesini amaçladıkları çalışmalarında Konya, Aksaray, Karaman, Ankara ve Gaziantep illerinde bulunan 26 farklı kümesteki yumurtacı tavuklardan 650 kan serum örneği toplamışlar ve oluşan antikorların varlığını ELISA testi ile belirlemişlerdir. Çalışmalarının sonuçlarına bakıldığında Toplam 650 kan serum örneğinden 113 (\%17.4)'ünde $O$. rhinotracheale antikoru tespit etmişlerdir. Çalışma sonunda bu pozitif örneklerin, örnekleme yapılan 26 kümesten $12(\% 46.2)$ 'sinden toplandığı ve bu enfekte 12 kümesin Konya, Gaziantep, Ankara ve Karaman illerindeki 12 farklı çiftliğe ait olduğu bildirilmiştir.

Canal ve ark. [6], Brezilya'nın güneyinde broiler tavukların (\%63.83) ve damılık broylerlerin (\%100) pozitifliğe sahip oldukları ve de sürülerde solunum semptomları ile $O$. rhinotracheale antikorları arasında pozitif bir ilişki olduğunu belirtmişlerdir. İran'ın Batı Azerbaycan Eyaleti'nde Allymehr [1] O. rhinotracheale'ye karş1 yapmış olduğu serolojik araştırmalarda tavuklardan alınan serum örneklerinin \%44.2'sini pozitif olarak bildirmiştir. Bundan birkaç yıl sonra, Ghanbarpour ve Mahmood [8] İran'ın Güney doğusunda yaptıkları bir çalışmada 8 farklı çiftlikte bulunan 21 kümesten 420 serum örneği ile çalışmışlardır. Çalışmalarında ELISA testi ile Ornithobacterium rhinotracheale'ye karş1 6 çiftlikte bulunan 17 kümeste 134 adet (\% 31.9) seropozitiflik saptamışlardır.

Mousavi ve ark. [10], İran'1n kuzeyindeki Guilan eyaletinde 2000 y1lında 30-35 ve 40-45 günlük broiler tavuk çiftliklerini kapsayan çalışmalarında 32 sürüden alınan 640 serum numunesini ELISA testi ile incelemiş ve sürülerin ORT'e karşı antikor tespit etmişlerdir. Sonuçta 10 sürüde $(\% 30.44)$ pozitif, 7 sürü (\%21.74) şüpheli, 15 sürü (\%7.82) istatiksel olarak negatif bulunmuştur. Toplanan 640 serum numunesinden, 30-35 günlük yaştaki sürülerde 24 pozitif, 30 şüpheli, 266 örnek ise negatif olarak tespit etmişlerdir. 40-45 günlük yaştaki numunelerde ise 178 numune pozitif, 77 numune şüpheli, 65 numunenin ise negatif olduğunu bildirmişlerdir. Yaptıkları çalışmada, ticari broiler tavuklarında antikor titreleri ile broiler yaşı arasında orantılı ORT antikor prevalansının pozitif korelasyon olduğunu tespit etmişlerdir $(\mathrm{p}<0.05)$. Çalışmamızda ise kesim yaşındaki broiler sürüleri incelendiği için yüksek pozitiflik oranlarının bundan kaynaklandığı düşünülmektedir.

Chansiripornchai ve ark. [7] Tayland' da yaptıklar1 ve Ornithobacterium rhinotracheale sero-prevalansının ülkelerinde ilk defa incelendiği çalışmada örnekleme yaptıkları tüm çiftliklerde pozitiflik saptamışlardır. İnceledikleri broiler çiftliklerinde $\% 19.8$ ve damızlık broiler çiftliklerinde ise $\% 49.8$ oranında pozitiflik bildirmişlerdir. Amerika Birleşik Devletlerinde yumurtaci tavuklarda yapılan bir araştırmada da örnekleme yapılan tüm çiftliklerde sero-pozitiflik saptanmış ve ELISA ile elde edilen ORT pozitiflik oranı ise çalışmamıza benzer şekilde $\% 52$ olarak bulunmuştur [9]. Uriarte ve ark. [15] Arjantinin Buenos Aires, Santa Fe, Entre Rios şehirlerinde ELISA ile yaptıkları araştırmada 739 adet serum analizinden 345 adeti (\%47) ORT serum pozitif tespit etmişlerdir. Baksi ve ark. [5] Hindistan'ın yedi eyaletinden alınan serum örnekleri ile ORT'ye karşı antikor varlığının tespiti için çalışmışlar ve \%74.37 düzeyinde pozitiflik saptamışlardır. Aynı zamanda araştırmalarında yaş ve mevsimin hastalik parametreleri üzerine etkisini de değerlendirmişlerdir. Kesim zamanı olarak değerlendirilen 4150 haftalık yaş grubu diğer yaş gruplarına göre en yüksek pozitiflik oranına sahip olarak bildirilmiştir. Araştırmalarının sonucuna göre hastalık en çok mu- 
son mevsiminde görülürken (\%88.31), kıș aylarında ise daha az (\%62.20) pozitiflik oranlarına sahip olduğu tespit edilmiştir. Araştırmamızda ise örnekleme Mayıs ayı içerisinde yapılmıştır. Bununla birlikte örneklemenin yapıldığ Ege bölgesinin batı kesimi ise hava sıcaklıklarının genelde yüksek olduğu yerler olarak söylenebilir. Bundan dolayıdır ki ülkemizin diğer yerlerine göre hastalığın biraz daha yüksek yüzde de görülebileceği düşünülmektedir.

Araştırmada aynı zamanda çiftlikler bazında da sonuçlar verilmiştir (Tablo2, 3 ve 4). İllerdeki çiftliklere göre yapılan değerlendirmelerde her üç ilde de yüksek pozitiflik oranlarına sahip olan çiftliklerin birbirlerine yakın olması oldukça dikkat çekici olarak kabul edilmiştir. Özellikle Aydın ilinde \%10.7 pozitiflik oranına sahip olan çiftlik diğer çiftliklere oldukça uzak olup çevresinde herhangi bir kanatlı barınağının bulunmaması çiftlikler arası bulaşmanın olabileceğini düşündürmektedir.

ORT hastalığının diğer viral hastalıklarla birlikte seyredebilmesi, ya da gösterdiği klinik belirtiler açısından birçok viral hastalıkla karıştırılması önemli bir risk faktörü olarak değerlendirilmektedir. Hastalığın tespitinde yapılan yanlış değerlendirmeler sonucunda özellikle büyük entegrelerin ciddi mali kayıplarla karşılaşacağı görülmektedir. ORT'nin ülkemize verdiği zararları tespit etmek için üstünde daha fazla çalışma ve araştırılma yapılması gereken bir konudur. Primer ya da sekonder olarak görülmesi ve sürekli yaşanılan solunum yönlü viral hastalıkların arkasına saklanması neticesinde yanlış aşılama ve koruyucu tedbirler nedeniyle yayılma eğilimi göstermesi ve içinden çıkılması güç durumlara kanatlı sektörünü sokması kaçınılmazdır. İleriki çalışmalarda serolojik çalışmaların yanında bakterinin izolasyonu ve identifikasyonunun da yapılarak çok değişken olabilen antibiyotik dirençliliklerinin de yapılarak tedavisi için gerekli tedbirlerin alınmas1 önerilebilir.

Solunum sistemini etkileyen hastalıkların tespiti yapılırken ORT'nin her zaman dikkate alınması ve ülkemizdeki yoğun kanatlı üretiminde gerekirse aşılama programlarına eklenmesi dâhil bütün koruma önlemlerinin alınması gerekmektedir.

\section{Teşekkür}

Çalışmada yapılan istatistiksel analizlerde yardımını esirgemeyen Sayın Prof. Dr. Erbay BAR-
DAKÇIOĞLU'na Teșekkür ederiz. Çalışma Adnan Menderes Üniversitesi Bilimsel Araştırma Projeleri Birimi tarafindan VTF-17013 nolu proje numarası ile desteklenmiştir. Ayrıca araştırmanın yapılmasında, Adnan Menderes Üniversitesi Hayvan Deneyleri Yerel Etik Kurulunun (HADYEK) 17.01.2017 tarihli 2017 y1l1 1. oturumunda alınan 64583101/2017/005 numaralı karar gereği etik aç1dan bir sakınca bulunmamıştır. Bu çalışma Veteriner Hekim Cenk GÜLLÜ’nün Yüksek Lisans Tez Çalışmasından özetlenmiştir.

\section{Kaynaklar}

1. Allymehr M, (2006). Seroprevalence of Ornithobacterium rhinotracheale infection in broiler and broiler breeder chickens in west Azerbaijan province, Iran. J Vet Med A $53,40-42$.

2. Aras Z, Sayın Z, Sanioğlu G, (2016). Serologic prevalence of Ornithobacterium rhinotracheale infection in commercial layers. Eurasian J Vet Sci. 32(1), 22-25.

3. Arda M, Minbay A, Aydın N, Akay Ö, İzgür M, (1994). Kanatlı Hayvan Hastalıkları, Genişletilmiş 3. Bask1, Ankara: Medisan Yayınevi Türkiye, 73-230.

4. Aşyemez AÜ, (2004). Güney Marmara bölgesinde hindi ve tavuklarda Ornithobacterium rhinotracheale infeksiyonu üzerinde bakteriyolojik ve serolojik çalışmalar. Doktora tezi. Uludağ Üniversitesi Sağlık Bilimleri Enstitüsü, Bursa.

5. Baksi S, Rao N, Chauhan P, (2017). Seroprevalence of Ornithobacterium rhinotracheale in broiler breeders in India. PSM Vet Res. 2(2), 29-32.

6. Canal CW, Leão JA, Ferreira DJ, Macagnan M, Salle CTP, Back A, (2003). Prevalence of antibodies against Ornithobacterium rhinotracheale in broiler and breeders in southern Brazil. Avian Dis. 47, 731-737.

7. Chansiripornchai N, Wanasawaeng W, Sasipreeyajan J, (2007). Seroprevalence and identification of Ornithobacterium rhinotracheale from broiler and broiler breeder flocks in Thailand. Avian Dis, 51, 777-780.

8. Ghanbarpour R, Mahmood S, (2009). Sero-prevalence and identification of Ornithobacterium rhinotracheale in broiler flocks in south-eastern Iran. Trop Anim Health Prod. 41, 1679-1683.

9. Heeder CJ, Lopes VC, Nagaraja KV, Shaw DP, Halvorson DA, (2001). Seroprevalence of Ornithobacterium rhinotracheale infection in commercial laying hens in the north central region of the United States. Avian Dis. 45, 1064-1067.

10. Mousavi SM, Hassanzadeh M, Khoshkhoo PH, Azad GA, (2012). Detection and Prevalence antibodies against Ornithobacterium rhinotracheale (ORT) by ELISA in broiler chicken farms in Guilan Province, Iran. Glob Vet. 8(2), 133-138.

11. Murthy TRGK, Dorairajan N, Balasubramanium GA, Dinakaran AM and Saravanabava K, (2008). In vitro antibi- 
otic sensitivity of Ornithobacterium rhinotracheale strains isolated from laying hens in India. Veterinarski Arhiv. 78, 49-56.

12. Özbey G, Öngör H, Balık DT, Çelik V, Kılıç A, Muz A, (2004). Investigations on Ornithobacterium rhinotracheale in broiler flocks in Elazig province located in the East of Turkey. Vet Med Czech. 49(8), 305-311.

13. Turan N, Ak S, (2002). Investigation of the presence of Ornithobacterium rhinotracheale in chickens in turkey and determination of the seroprevalence of the infection using the enzyme-linked immunosorbent assay. Avian Dis. 46, $442-446$.

14. Türkyılmaz S, Kaya O, (2005). Detection of antibodies produced against Ornithobacterium rhinotracheale and Bordetella avium by Enzyme-Linked Immunosorbent Assay in hens and turkeys in Aydın Province, Turkey. Turk J Vet Anim Sci. 29, 897-902.
15. Uriarte J, Corva S, Gornatti D, Origlia J, Píscopo M, Cerda R,Herrero M, Marcantoni H, Unzaga MF, Marino F, Spinsantti E,Pecoraro M, Petruccelli M, (2010). Evidencia serológica de infección en aves comerciales por Ornithobacterium rhinotracheale (ORT) en las provincias de Buenos Aires y Entre Ríos (Argentina). Analecta Vet. 30(1), 34-36.

16. Van Empel PCM, Hafez HM, (1999). Ornithobacterium rhinotracheale: a review. Avian Pathol. 28, 217-227.

17. Vandamme P, Segers P, Vancaneyt M, van Hover K, Mutters R, Hommez J, Dewirst F, Paster B, Kersters K, Falsen E, Devrieze L, Bisgaard M, Hinz KH, Mannheim W, (1994). Description of Ornithobacterium rhinotracheale gen. nov. sp. nov. isolated from the avian respiratory tract. Int J Syst Bacteriol. 44, 24-37.

18. Zorman-Rojs O, Zdove I, Bencina D, Mrzel I, (2000). Infection of turkeys with Ornithobacterium rhinotracheale and Mycoplasma synoviae. Avian Dis. 44, 1017-1022. 